\title{
EQUAL OPPORTUNITIES IN ROMANIAN POLITICS - WORK IN PROGRESS. A CHRONOLOGICAL AND SPATIAL ANALYSIS OF WOMEN'S PARTICIPATION IN POLITICAL LIFE
}

DOI: https://doi.org/10.18509/GBP210237f

UDC: 323.21-055.2(498)

324-055.2(498)

\author{
Andreea-Daniela Fedor \\ Marinela Istrate \\ Corneliu Iațu \\ Department of Geography, Faculty of Geography and Geology, Alexandru Ioan Cuza \\ University of Iasi, Iasi, Romania
}

\begin{abstract}
The political parties play a unique and fundamental role within the democratic process and they can also play a significant role in what concern the opportunities to promote women in political structures. Thus, the present paper seeks to describe the way in which the main political parties supported the women's involvement within political life at local level (mayors) from 1996 till present. In order to realize the study, quantitative methods are going to be used, the data being collected from the official sites regarding the local elections. In this sense, there were analyzed the 1996-2020 databases that concern: the candidates, their parties and their gender, the winners and their parties, the voters' turnout. The results show that the percentage of female candidates proposed by the parties is slightly increasing, but it does not exceed the $10 \%$ threshold, a sign that gender equality is more accepted in theory than in practice. The study focuses on women candidates who have been nominated by parties to run, but also those who have won. Interesting are the situations by parties and two trends can be observed: large parties neglect the attention given to women, these being below the national average (PSD, PNL), and small or newly founded parties promote them to a greater extent.
\end{abstract}

Keywords: political parties, female mayors, local politics.

\section{INTRODUCTION}

Political parties are the key gate-keepers and power players for fair representation of women and ethnic or racialized minorities [1] (Kantola, 2018) and their policies can promote women within political life or block their access. However, it must be emphasized that Romania's experience with pluralism is not a vast one, being able to talk about such a thing on the Romanian territory only during 1918-1938 and then, after the Fall of Communism in 1989. However, the just founded parties (in 1989) were not born out of conflicts of different social interests, their connection with the social environment being weak [2] (Ingrid van Biezen, 2003). In what concerns the women's representation in local politics (mayors), in Romania the first three female mayors were elected in 1930, when they had the right to vote only under specific conditions ${ }^{5}$, but there was no

\footnotetext{
${ }^{5}$ The 6th Article of the 1923 Constitution: Special laws, voted by a two-thirds majority, will determine the conditions under which women can exercise political rights. Women's civil rights will be determined on the basis of full gender equality.
} 
specification about the right to be elected. In municipal and county election of the same year many personalities involved in women's emancipation as Ella Negruzzi, Calypso Botez, Margareta Paximade-Ghelmeceanu, Ortansa Satmary ${ }^{6}$ were on the electoral lists of the National Peasant Party, while Sarmiza Bilcescu-Alimăneştianu or Maria Pillat ${ }^{7}$ on the electoral lists of the National Liberal Party. Following the election, more than a hundred women became counselors across the country [3] (Ştefania Mihăilescu, 2006,). Despite the fact that early first steps were taken in Romania, women's political participation at local level remains a significat challenge, as the communist party let deep scars translated through decorative participation [4] (Ghebrea, 2015). In other words, the female's representation in politics, education, was only to consolidate power and create a large workforce [5,6] (Massino, 2004; Ciucă, 2010) and not to guarantee gender equality. Thus, women actively participated in the mass culturalization campaign, in all electoral activities from the position of mother, worker and citizen, but not because of their status as women, having a well-defined program of action, with specific claims and tailor-made solutions, women being seen as a means of transfer [7] (Cosma \& Țârău, 2002). Women were in the attention of the Communist Party and occupied party secretaries' seats at county level, ministers' seats and there were gender quotas. These were short-term solution, which did not bring any input or inertia, so once the imposed quotas were removed, the gaps increased. Therefore, only after the fall of the Communism we have a clearer image in what concern women's representation in politics.

Yet, soon after 1989 there was an unstable society, emerging from communism, with problems related to respecting the fundamental rights and freedoms. Thus, the presence of women in politics is equivalent to marginalization, and the difficult construction of solid legislation and law enforcement issues have made the women's presence even more complicated in this area. Of course, there is also the positive legacy of communism - a clear improvement in the status of women and a policy of equal opportunities, maintained in accordance with current legislation [8,9] (Gal, Kligman, 2003; Matei, Iațu, Vert, 2010). On the other hand, there was inherited the traditional mentality that the main duties of women are related to the birth, upbringing and education of their children [9] (Matei, Iațu, Vert, 2010) and the negative image of women promoted by the party that led to the projection of this image on women in post-December politics [4] (Ghebrea, 2015).

\section{METHODOLOGY}

\section{Study area}

The study area of the present research is Romania and it takes into consideration the NUTS 2 and NUTS 3 Regions (Fig. 1.). The eight development regions have an average of 2,42 million inhabitants as the population varies from 1,77 millions in the West to more than 3 million inhabitants (Table 1.) in the North-East Region

The 108 Articol of the 1923 Constitution: The members of the county councils and the communal councils are elected by the Romanian citizens by universal, equal, direct, secret, obligatory and minority representation, according to the forms provided by the law. They will be able to add by law and law members and co-opted members. Among co-op members may be major women.

(http://www.cdep.ro/pls/legis/legis_pck.htp_act_text?idt=1517)

${ }^{6}$ Intellectual women of the period, suffragists and women's right activists.

${ }^{7}$ Intellectual women of the period, suffragists and women's right activists 


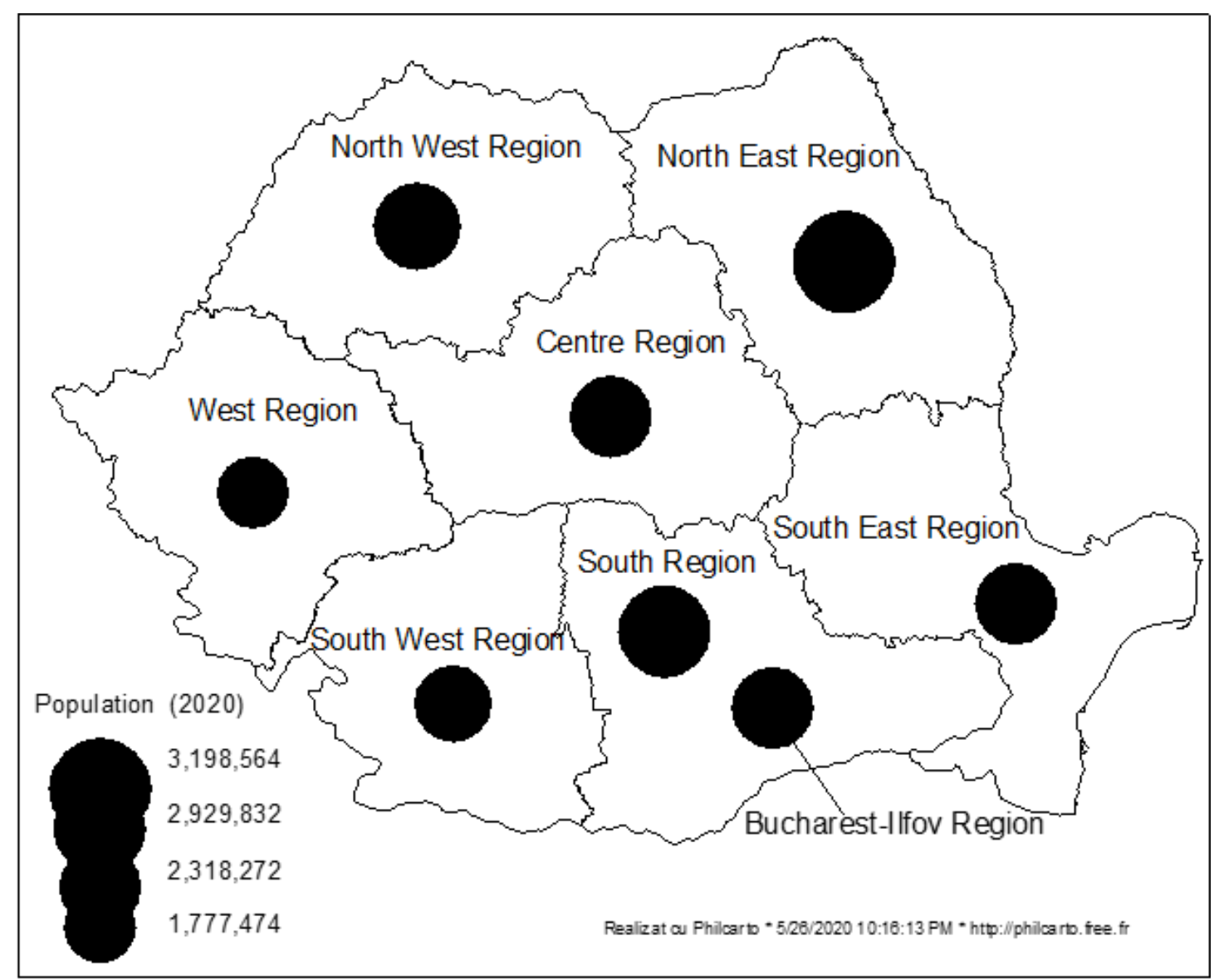

Figure 1. Administrative structure of Romania and their population (NUTS 2). Data source: INS [17]

Table 1. The Romanian population by region. Data source: INS

\begin{tabular}{|l|l|l|l|}
\hline Region & $\begin{array}{l}\text { Population } \\
(2020)\end{array}$ & $\begin{array}{l}\text { Population above 18 } \\
\text { years old (with voting } \\
\text { right) }\end{array}$ & $\begin{array}{l}\text { \% Population with voting } \\
\text { right out of the total } \\
\text { population }\end{array}$ \\
\hline North-East Region & 3198564 & 2460068 & 76.91 \\
\hline South Region & 2929832 & 2369795 & 80.89 \\
\hline North West & 2552112 & 2037147 & 79.82 \\
\hline South-East Region & 2396171 & 1917418 & 80.02 \\
\hline Central Region & 2318272 & 1836644 & 79.22 \\
\hline Bucharest - Ilfov & 2315173 & 1895735 & 81.88 \\
\hline South-West Region & 1926860 & 1577683 & 81.88 \\
\hline West Region & 1777474 & 1449463 & 81.55 \\
\hline
\end{tabular}

Statistical data used

To carry out the study, quantitative (analysis of electoral results) and qualitative methods were combined. The data were collected from official local election websites (BEC and Prezență vot) [18]. In our research we analyzed the local elections of 1996, 2000, 2008, 2012, 2016 and 2020 based on: candidates, their parties and gender, winners and their parties, gender and turnout. The graphical method will be used in designing the results. It should be noted that in 2000 there are no officially validated statistics on the number of candidates, their gender nor the party to which they belong. Therefore, we take into account the fact that our analysis may be influenced by this lack of data. Also, for 1996, 2008 and 2020 the official databases were not classified by gender, which means that they were processed manually and we are aware that there may be a margin of error of 3-5\%. 


\section{RESULTS AND DISCUSSIONS}

Regarding the participation in the electoral process and women's political representation, the results of the analyzed data show that they are reduced in the structures of the local administration in the 1992-2020 legislature, from $1,4 \%$ to 5,33\%. More precisely, out of more than 3200 seats the female candidates won 71 in $1996(2,44), 93$ in 2000, 100 in 2004 (3,43), 104 in 2008 (3,31), 116 in 2012, 144 in 2016 (4,58), and 165 in 2020 $(5,33 \%)$.

Despite the fact that the first female mayors were elected in 1930, we can see in Fig. 2. that the evolution of the percentage of female mayors is very slow and difficult. Also, compared to the EU average 13\% in 2011, approx. 15\% in 2017 (Fig. 3.), this share is very low, but it is noted that including at European Union level the growth is quite slow.

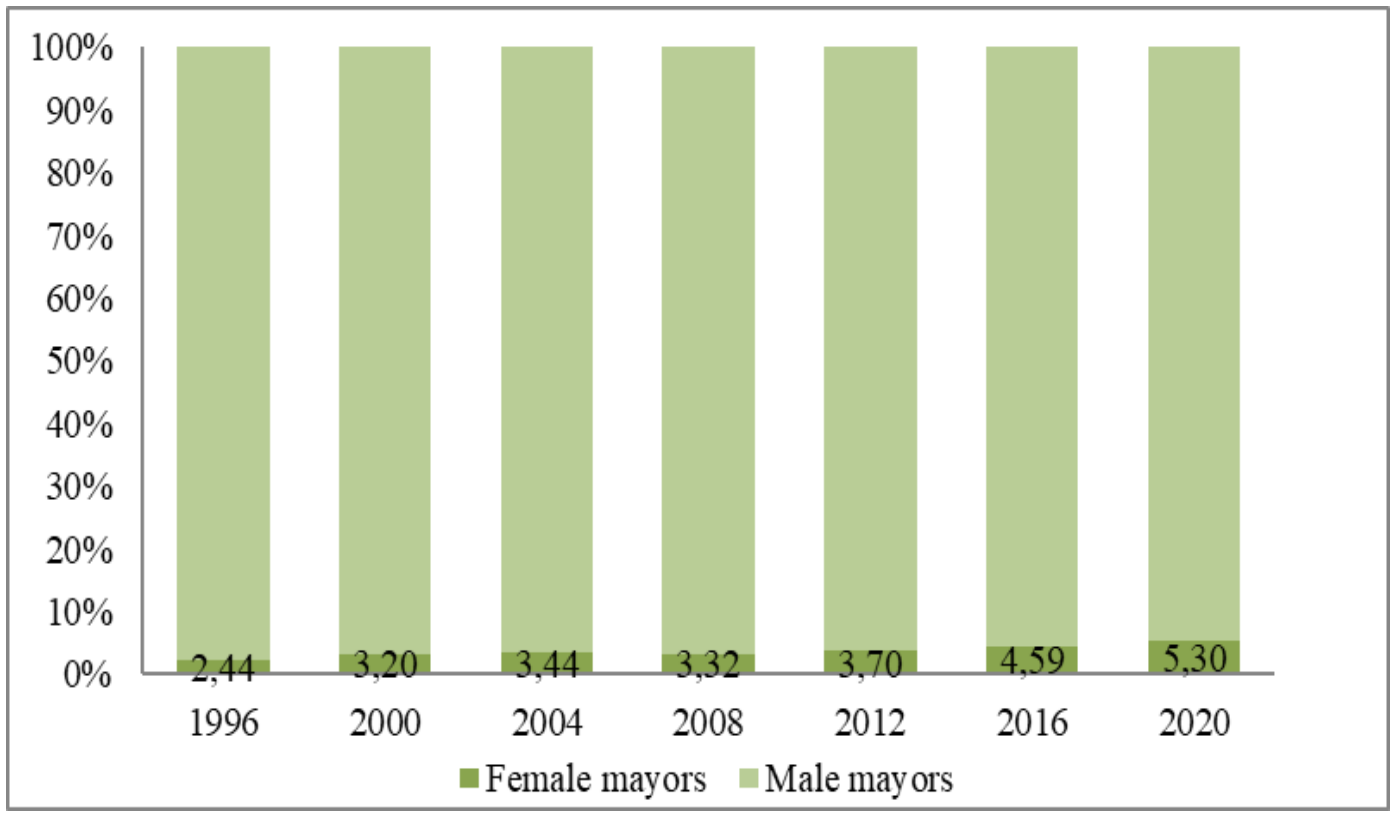

Figure 2. The evolution of male and female mayors in Romania, 1996- 2020. Data source: roaep.ro and BEC

The low level of female mayors (Fig. 2.) can be translated into "absence syndrome" [10] (Tekeli, 1991), if we correlate it to the concept of a critical mass of $35 \%$ or more at which women's representation reaches a 'tipping point' [11-13] (Childs \& Krook 2008, Lewis \& Simpsons, McGregor \& Webster 2017). In Romania none of the eight regions (NUTS 2) has exceeded the threshold of $35 \%$ (Fig. 4.).

This absence can be understood through at least two hypotheses: after 1990 women preferred to pursue a professional career and since there has been no trend in women's participation in politics, they focused on other departments or they avoided the politics as class it had not a great reputation, and mass media contributed to the women's pejorative categorization [14] (Băluță, 2012).

It is very important to understand the political mechanisms (specific to the partisan space and the functioning of the current Romanian political space) that maintain a reduced presence of women in the post-December Romanian politics [14] (Băluță, 2012). The elections in Romania are conducted on the basis of a closed party list system, thereby each party has a key role in determining the number of women candidates and their place on the lists. 


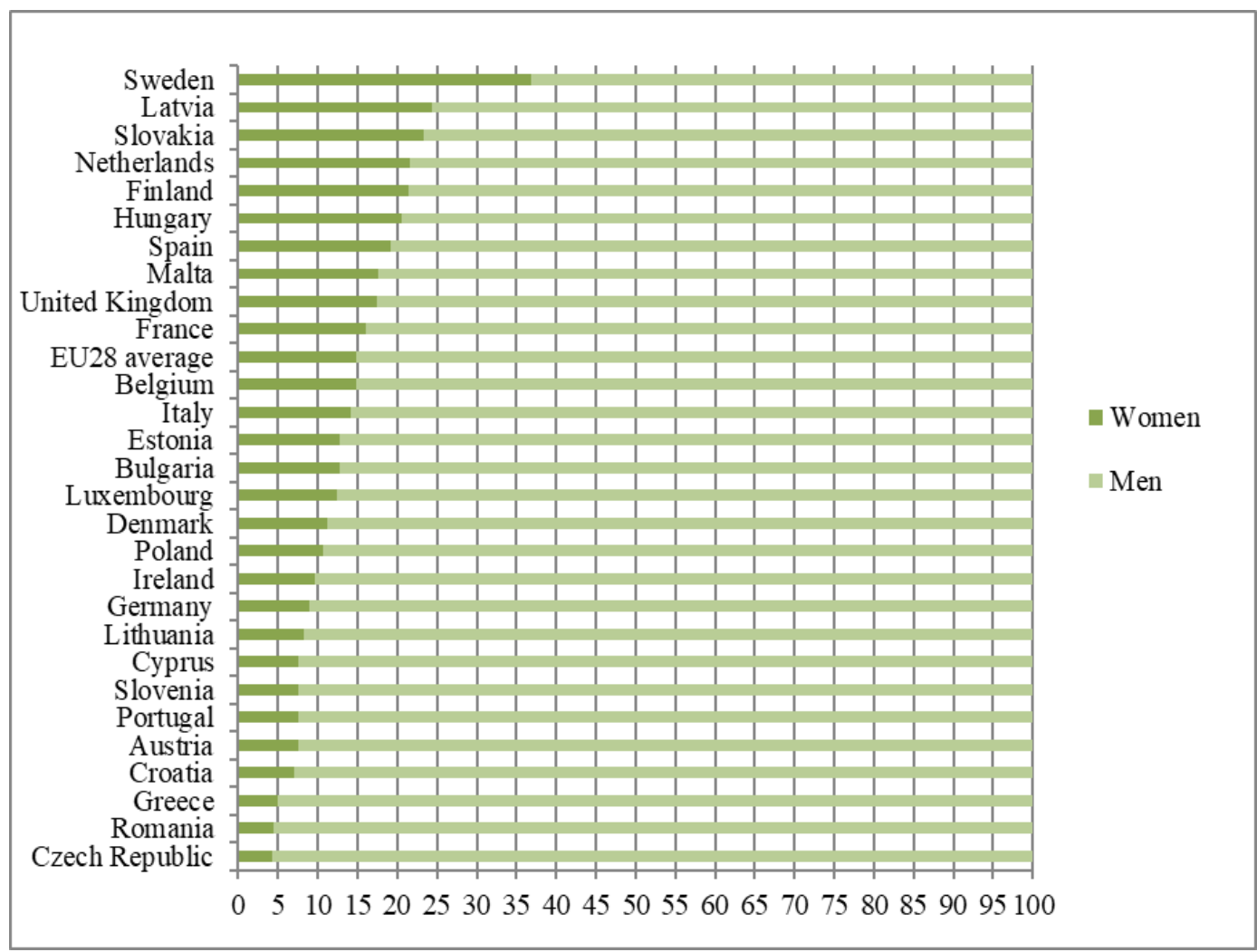

Figure 3. The percentage of male and female mayors within European Union (28 countries) in 2017. Source of the data: EIGE https://eige.europa.eu

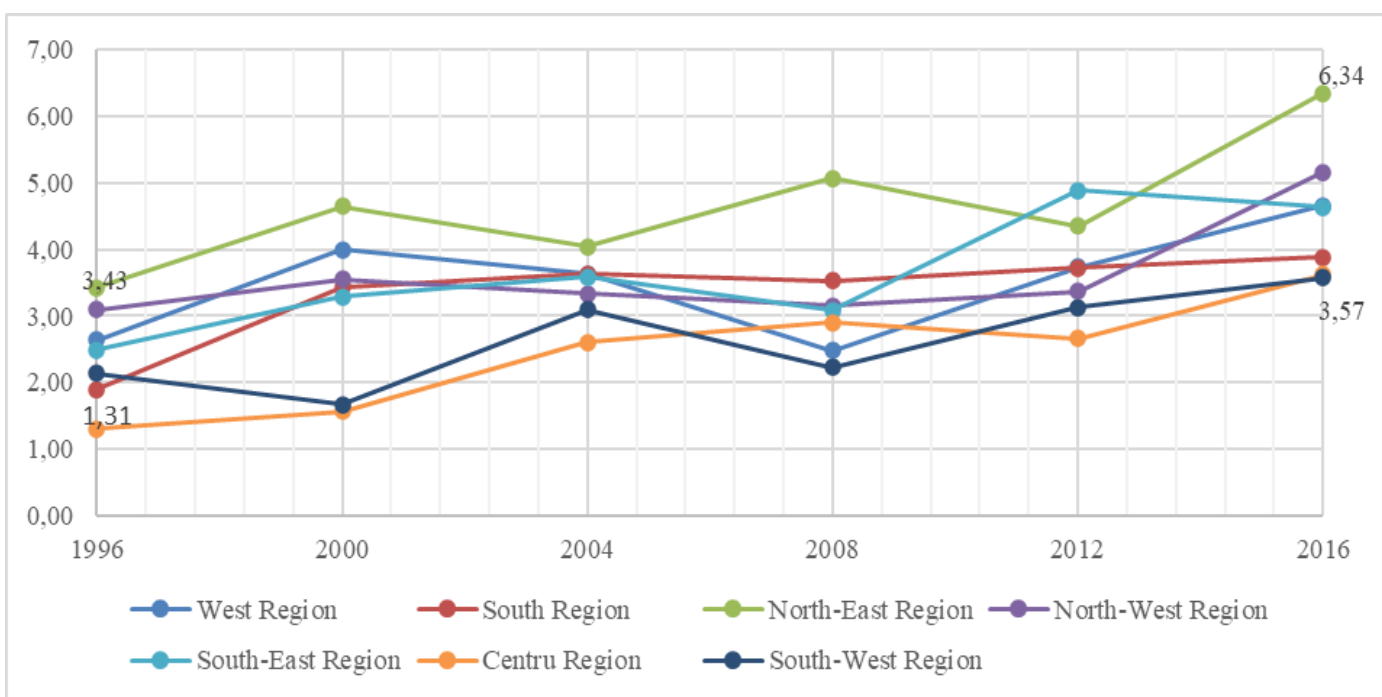

Figure 4. The evolution of female mayors (\%) in Romania by NUTS 2 within 1996-2016 period. Data source: roaep.ro and BEC

The recruitment of women can be affected by shadowy arrangements as male-dominated networks influence political parties' candidate selection [15] (Sundstrom, 2014). The Law on Political Parties is silent on the way in which parties nominate their own candidates and does not contain any conditions on internal party democracy, so that each party is free to nominate its candidates as considered. The most important parties in Romania have a women's organization, which can be a useful training ground for women, where they can develop political skills and techniques. However, women's organizations tend to 
support a system in which women remain outside the central, decision-making activities of the party as no party has developed special policies to promote women in politics.

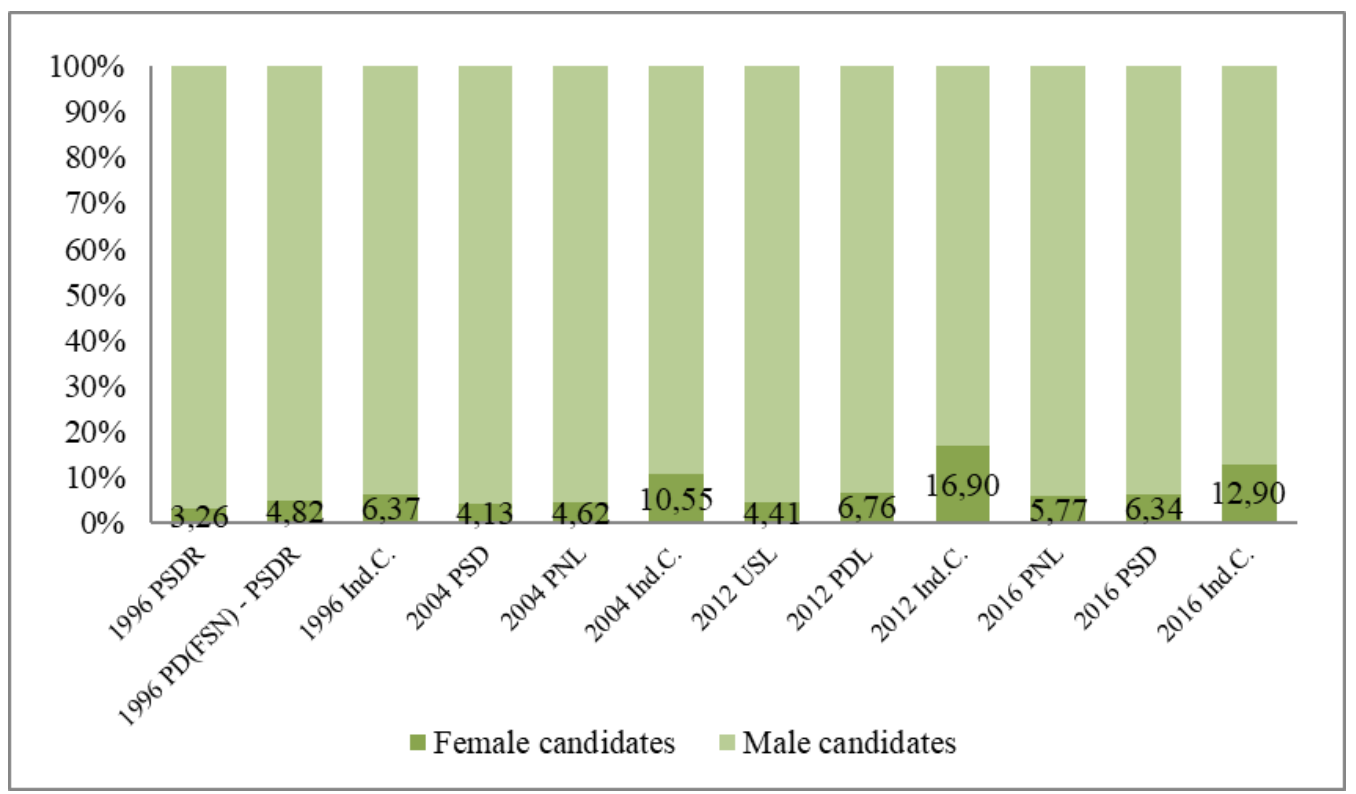

Figure 5. The percentage of male and female candidates of the most important parties and alliances in 1996, 2004, 2012 and 2016. Data source: roaep.ro and BEC

Moreover, it was observed that till 2016 the $10 \%$ threshold of female candidates was exceeded only by the independent candidates and almost reached $(9,1)$ by the populist political party, People's Party - Dan Diaconescu, that was new and won a total of 31 mayoral seats (less than 1\% of total). The parties that won the most seats put on their lists, over the years, less than 6\% female candidates (Fig. 5.) and their success rate is lower when compared to the male candidate's rate.

Another aspect that may have negatively influenced the female's political presence within the local politics (mayors) could have been the one round system that from 2012 contributed to the decrease of candidates (both male and female) (Fig. 6.). Majority is a principle of democracy, so the candidate must be elected by $50 \%+1$ of the voters to represent them [16](Birch, 2003). This principle in Romania was theoretically ensured thanks to the elections in two rounds, but starting with 2012 the local elections are validated after a single round. This decision clearly benefits strong political parties and can be a disadvantage for small parties, women and minorities.

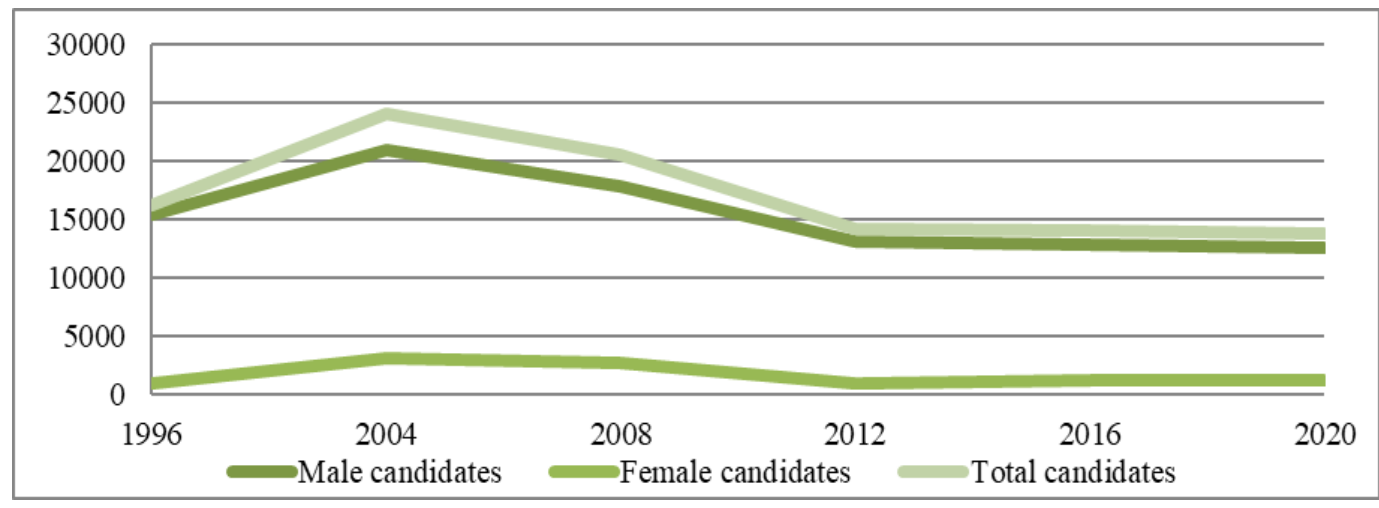

Figure 6. The evolution of the number of candidates in Romania (total, male, female) 1996-2020. Data source: roaep.ro and BEC 


\section{CONCLUSION}

The present results show that the trend of women's participation in local politics has been increasing from one election to another which is significant, but the current relatively young democracy and socio-economic transition may explain this phenomenon. Yet, there is a long way till reaching equal representation, or, at least the tipping point, as that the parties do not have a strategy in promoting women. The low interest of the parties in promoting women may explain the low chances and rates of success. Perhaps imposing a female participation quota to the parties would lead to a greater involvement, of both parties and women, with the possibility of better political assertion, but it is difficult to predict the impact. Moreover, the role of Romanian society and the distrust manifested in women politicians (Euro barometers 465 and 493 ) and, maybe, the lack of successful models. If there are models in business, in the media, in politics they are less present, and the performance of some women politicians led to the decrease of confidence in women politicians.

\section{REFERENCES}

[1] Kantola, J. Women's Organizations of Political Parties: Formal Possibilities, Informal Challenges and Discursive Controversies, NORA - Nordic Journal of Feminist and Gender Research, vol. 27:1, pp 4-21, 2019

[2] Ingrid van Biezen, Patterns of Party Organization in New Democracies: A Comparative Assessment of Southern and East-Central Europe, paper prepared for the panel „Post-Communist Party Developement", APSA, USA, 2003

[3] Mihăilescu, Ş., Din istoria feminismului românesc: antologie de texte: 1838-1929, Romania, 2002

[4] Ghebrea, G., Contextul de acţiune a egalităţii de gen înainte de 1989, Statutul femeii în România comunistă, Romania, pp 27, 2014

[5] Massino, J., Anonimatul femeii în estetica României ceauşiste, in Alin Ciupala "Despre istoria femeilor în România", Universitatea Bucuresti Romania, 2004

[6] Ciucă, O. L., Etapele ideologizării conceptului de emancipare a femeii, Romania, pp 74- 90, 2010

[7] Ghizela, C., Virgiliu, T.., De la diversitate la integrare. „Problema femeii" şi instaurarea comunismului în Europa Centrală şi de Est: Cazul României, Condiţia femeii în România secolului XX. Studii de caz, Romania, pp 135-159, 2002

[8] Gal, S., Kligman, G., Politicile de gen în perioada postsocialistă, Romania, pp 125-146, 2003

[9] Matei, E., Iațu, C., Vert, C., Romanian Woman Involvement in Governance after 1990, Geographica Pannonica, Serbia, vol. 14:1, pp 1-13, 2010

[10] Tekeli, Ș, 55-Year Story of Women's Exclusion from Politics, Women and Political Life: Equal Right-Equal Participation, Turkey, 1991.

[11] Childs, S., Krook, M., Critical Mass Theory and Women's Political Representation. Political Studies, vol 56:3, pp 725-736, 2008

[12] Lewis, P. and Simpson, R. Kanter, Gender, power and (in)visibility. International Journal of Management Reviews, vol 14:2, pp 141-158, 2012

[13] McGregor, K, Webster, J., Women's local government representation in Auckland - does size matter?, Commonwealth Journal of Local Governance, Australia, Issue 20, pp 1-20, 2017 
[14] Băluță, I., Femeile în spațiul politic din România postcomunistă: De la ,jocul” politic la construcția socială, Annals of the University of Bucharest / Political science series, Romania, vol. 14:2, pp 87-95, 2012

[15] Sundstrom, A., Wängnerud, L. Corruption as an obstacle to women's political representation: Evidence from local councils in 18 European countries, Party Politics, vol. 22:3, pp 354-369, 2014

[16] Birch, S., Two-Round Electoral Systems and Democracy. Comparative Political Studies. 2003;36(3):319-344

[17] Institutul National de Statistica [INS] [National Institute of Statistics], http://www.insse.ro/ [18] Biroul Electoral Central [BEC] [Central Electoral Office], https://www.bec.ro/ 